\title{
Sektor węglowy Unii Europejskiej na początku XXI wieku - import zamiast wydobycia?
}

\author{
Coal sector in the European Union \\ at the beginning of 21 st century \\ - imports displacing production?
}

\section{Maciej Kaliski}

Wydział Wiertnictwa, Nafty i Gazu, Akademia Górniczo-Hutnicza w Krakowie

\section{Miłosz Karpiński}

przedstawiciel RP przy Międzynarodowej Agencji Energi

\section{Marian Turek}

Wydział Organizacji i Zarządzania, Politechnika Śląska

\section{Abstract}

One of the most important dilemmas faced by the European Union is the decision on the scale of using fossil fuels - in particular coal, in covering the demand for energy. Currently, there are numerous discussions concerning the restriction of the use of this energy carrier by the EU countries, which, as a result, is to reduce air pollution on a global scale. The article presents the use of energy carriers in particu-lar regions of the World and forecasts regarding the use, in particular of coal in the period up to 2040, and the possible impact of the $\mathrm{EU}$ on reducing $\mathrm{CO}_{2}$ emissions as a result of abandonment of coal. The results of actions undertaken by EU co-untries in the area of limiting the use of coal were presented. The authors also draw attention to the issue of energy security in the context of a steady increase in the import of energy carriers, in particular coal.

Keywords - coal, energy security, energy balances 


\section{Światowe zużycie energii}

Od pewnego czasu trwaja w Unii Europejskiej dyskusje dotyczace polityki w zakresie pokrycia zapotrzebowania na energię. Dyskusja ta dotyczy struktury bilansu energetycznego i wykorzystywanych nośników energii. Głównym powodem prowadzonej debaty jest próba ograniczenia emisji gazów cieplarnianych i zmniejszenie ich wpływu, w skali globalnej, na zmiany klimatu. Mając na uwadze znaczne różnice w strukturze bilansu energetycznego poszczególnych państw członkowskich debata ta jest niezwykle skomplikowana. Jednym z głównych postulatów zgłaszanym w trwającej debacie jest znaczne ograniczenie lub wręcz całkowite zaniechanie wykorzystania jednego z podstawowych nośników energii jakim jest węgiel. Podjęcie tak radykalnej decyzji dla części państw UE może wywołać znaczne implikacje społeczno-gospodarcze, przy jednoczesnym braku jakichkolwiek gwarancji, że planowany cel, tj. ograniczenie emisji gazów cieplarnianych w skali światowej, zostanie osiągnięty.

Jednak, aby rozpatrywać możliwość rezygnacji lub znacznego ograniczenia wykorzystania węgla w bilansie energetycznym Unii Europejskiej należy spojrzeć na zużycie energii i wykorzystywane nośniki energii w kontekście globalnym.

Analizując światowe zużycie energii pierwotnej w ostatnich 26 latach należy zauważyć, że wzrosło ono aż o około 63\% i w roku 2016 wynosiło 13 276,3 Mtoe ${ }^{1}$ [1]. Rozwój gospodarczy poszczególnych regionów świata jest ściśle związany ze zużyciem energii. Dlatego tė̇, zużycie energii, należy rozpatrywać w podziale na poszczególne regiony.

Największy wzrost zużycia energii pierwotnej w analizowanym okresie miał miejsce na Środkowym Wschodzie, w roku 2016 zużycie to wynosiło 894 Mtoe i względem 1990 roku odnotowano wzrost aż o $230 \%$ [ibidem].

Kolejnym regionem pod względem wzrostu zużycia energii pierwotnej były Azja i Ocenia, gdzie odnotowano wzrost o 208\% (w roku 2016 zużycie wyniosło 5447,4 Mtoe) [ibidem].

Następnie Ameryka Centralna i Południowa - wzrost zużycia energii pierwotnej o 110\% (w roku 2016 wynosiło 705,3 Mtoe), Afryka - wzrost zużycia o 98\% (w roku

\footnotetext{
${ }^{1}$ Mtoe (ang. Million Tonnes of Oil Equivalent) - mega tona oleju ekwiwalentnego - to energetyczny równoważnik jednej metrycznej tony ropy naftowej o wartości opałowej równej $10000 \mathrm{kcal} / \mathrm{kg}$. Używana przede wszystkim w energetyce do opisu dużych wartości energii. Międzynarodowa Agencja Energetyczna (IEA) i Organizacja Współpracy Gospodarczej i Rozwoju (OECD) definiują 1 toe jako $11630 \mathrm{kWh}=11,63$ MWh.
} 
2016 wynosiło ono 440,1 Mtoe), Ameryka Północna - wzrost o 20\% (w roku 2016 zużycie energii pierwotnej wynosiło 2788,9 Mtoe) [ibidem].

Zdecydowanie odmiennie sytuacja wygląda w Europie i Eurazji, gdzie zużycie energii pierwotnej w analizowanym okresie zmniejszyło się o 11\% i w roku 2016 wynosiło 2867,1 Mtoe. Natomiast w przypadku Unii Europejskiej zużycie energii pierwotnej w okresie od 1990 do roku 2016 zmniejszyło się o niespełna 2\% [ibidem].

Na rysunku 1 przedstawiono zmianę zapotrzebowania na energię w poszczególnych rejonach świata i w Unii Europejskiej.

Rysunek 1. Zużycie energii pierwotnej na świecie w okresie od 1990 do 2016 roku [Mtoe]

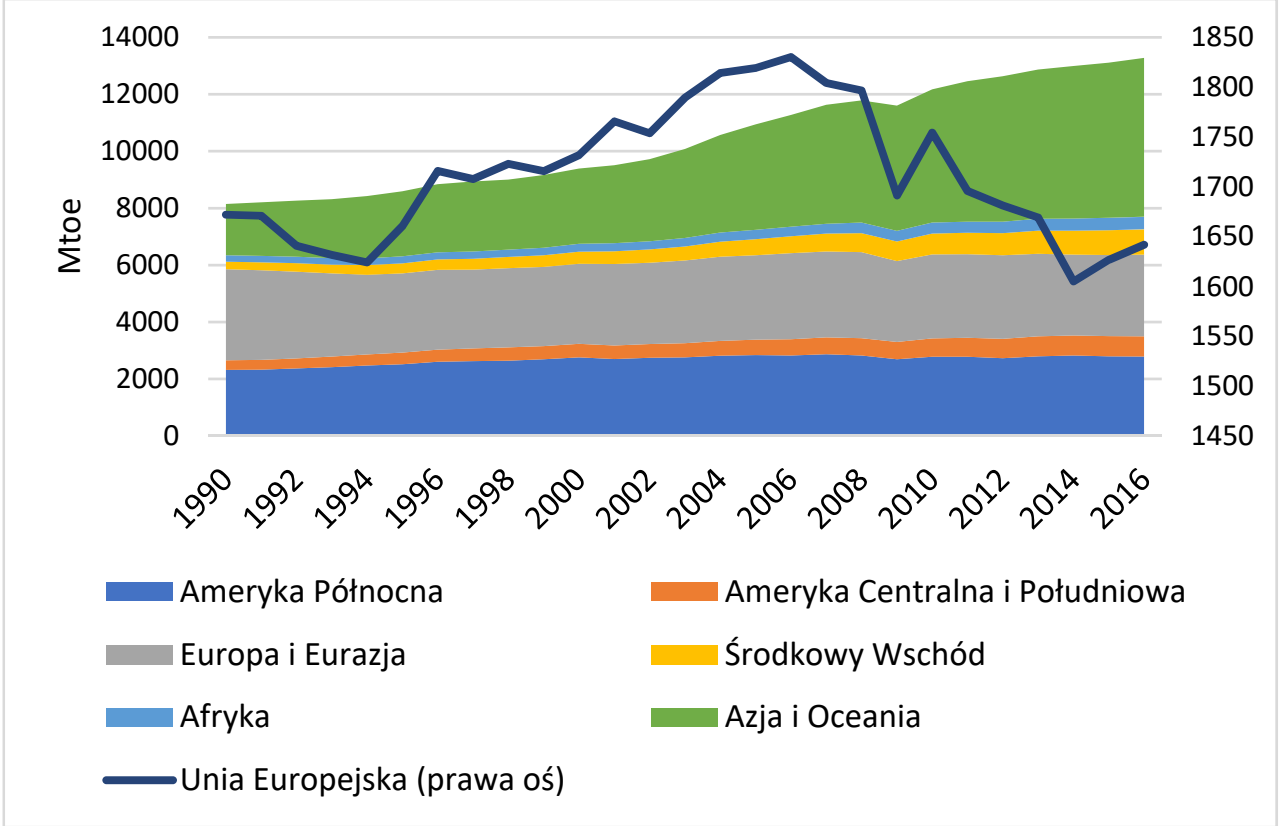

Źródło: opracowanie własne na podstawie [1].

Biorąc pod uwagę strukturę światowego zużycia energii pierwotnej zależy zaznaczyć, że w okresie od roku 2002 do 2016 dominującą rolę odgrywała ropa naftowa, której udział w bilansie energii pierwotnej charakteryzował się tendencją spadkową i wynosił od $37,6 \%$ do 33,3\%. Na drugim miejscu w bilansie znajdował się węgiel, którego udział 
wzrastał i wynosił od 25,5\% do 28,9\%. Kolejnym nośnikiem energii, którego udział w bilansie jest znaczacy to gaz ziemny, a jego udział był niemal niezmienny i wynosił $24 \%$ [1].

Dopełnieniem światowego bilansu energetycznego była energia jądrowa - której udział zmniejszał się od 6,5\% do 4,4\% oraz energetyka wodna - której udział nieznacznie wzrósł od 6,3\% do 6,7\%. Należy zwrócić uwagę, że od roku 2010 w publikacjach Międzynarodowej Agencji Energii dotyczących struktury światowego bilansu energetycznego, pojawiły się odnawialne źródła energii, których udział w roku 2016 wynosił 2,8\%. Należy jednak mieć na uwadze, że analizowanym okresie kopalne nośniki energii były głównym źródłem pokrywającym światowe zapotrzebowanie na energię pierwotna, a ich łączny udział wynosił od 85\% do 87\% [ibidem].

Na rysunku 2 przedstawiono udział poszczególnych nośników energii w światowej strukturze bilansu energetycznego.

Rysunek 2. Udział nośników energii w światowym bilansie energetycznym w latach 2002-2016

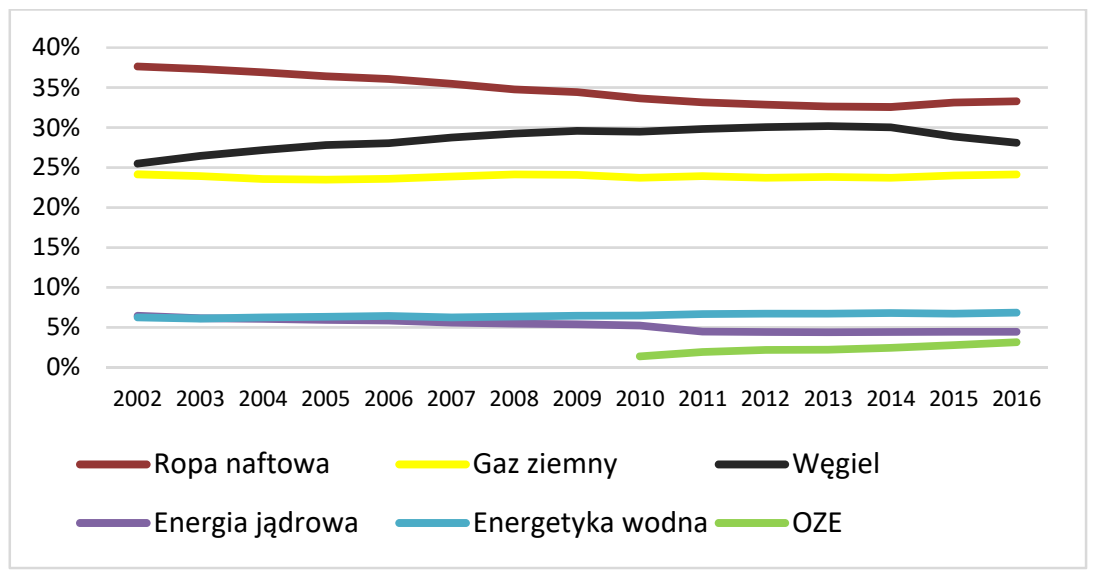

Źródło: opracowanie własne na podstawie [1].

\section{Prognozy Międzynarodowej Agencji Energii (IEA)}

Zgodnie z prognozami Międzynarodowej Agencji Energii, przedstawionymi w publikacji World Energy Outlook 2017, przewiduje się, że globalne potrzeby energetyczne w perspektywie do roku 2040 będą wciąż wzrastać, jednak ten wzrost będzie mniejszy 
i będzie wynosił około 30\%. Pomimo mniejszej dynamiki wzrostu należy mieć na uwadze, że będzie on stanowił ekwiwalent obecnego łącznego zużycia Chin i Indii - około 3800 Mtoe. Prognozy wzrostu zapotrzebowania na energię IEA oparło na szacunkach, że globalny rozwój gospodarczy będzie wzrastał w tempie średnio 3,4\% rocznie (łącznie o 125\% do roku 2040), natomiast prognozowany wzrost populacji, oszacowano z 7,4 miliarda osób dzisiaj do 9 miliardów w roku 2040. Z przedstawionych prognoz wynika, że w wyniku postępującego procesu urbanizacji co cztery miesiące powstaje nowe miasto wielkości Szanghaju [2].

Zgodnie z prognozami, największy udział we wzroście popytu na energię, prawie 30\%, przypadnie na Indie, których udział w globalnym zużyciu energii w roku 2040 osiagnie $11 \%$ - przy 18-procentowym udziale w przewidywanej populacji globu. Nośnikiem energii który pokryje prognozowany wzrost zapotrzebowania ma być węgiel, którego zużycie wzrośnie dwukrotnie i wyniesie 1,2 mld ton w roku 2040. Obecnie udział węgla w wytwarzaniu energii elektrycznej w Indiach wynosi 75\% i, mimo dwukrotnego wzrostu zużycia w wartościach realnych, ten wskaźnik spadnie do $50 \% \mathrm{w}$ roku 2040 [ibidem].

Kolejnym rejonem pod względem wzrostu zapotrzebowania na energię jest Południowo-Wschodnia Azja, gdzie popyt na energię będzie wzrastał w tempie dwukrotnie większym niż w Chinach. Generalnie, rozwijające się kraje w Azji będą odpowiedzialne za dwie trzecie globalnego wzrostu popytu na energię, reszta przypadać będzie na kraje z rejonów Bliskiego Wschodu, Afryki i Ameryki Lacińskiej [ibidem].

Wraz ze wzrostem zapotrzebowania na energię niezbędne będą inwestycje w infrastrukturę energetyczną, która umożliwi efektywny jej transport do odbiorców. Chiny, aby sprostać rosnącemu zapotrzebowaniu, zmuszone będą do roku 2040 dokonać inwestycji których ekwiwalent stanowił będzie odpowiednik dzisiejszego systemu energetycznego Stanów Zjednoczonych. Natomiast inwestycje w sektor energetyczny Indii stanowić będą ekwiwalent systemu energetycznego Unii Europejskiej. Przedstawione porównania obrazują skalę wyzwań przed jakim stoi światowy system energetyczny oraz szereg ryzyk z tym związanych [ibidem].

Jednak pomimo globalnego wzrostu popytu na energię, w szczególności na energię elektryczna, w całej Azji, Afryce i Ameryce Południowej, to w rejonach najbardziej rozwiniętych - tj. w UE, USA i Japonii - prognozuję się, że zapotrzebowanie na energię, 
względem roku 2016, spadnie. Na rysunku 3 przedstawiono prognozowany wzrost zapotrzebowania na energię w okresie do roku 2040 z podziałem na poszczególne regiony świata [2], [3].

Rysunek 3. Zmiana zapotrzebowania na energię w okresie 2016-2040 [Mtoe]

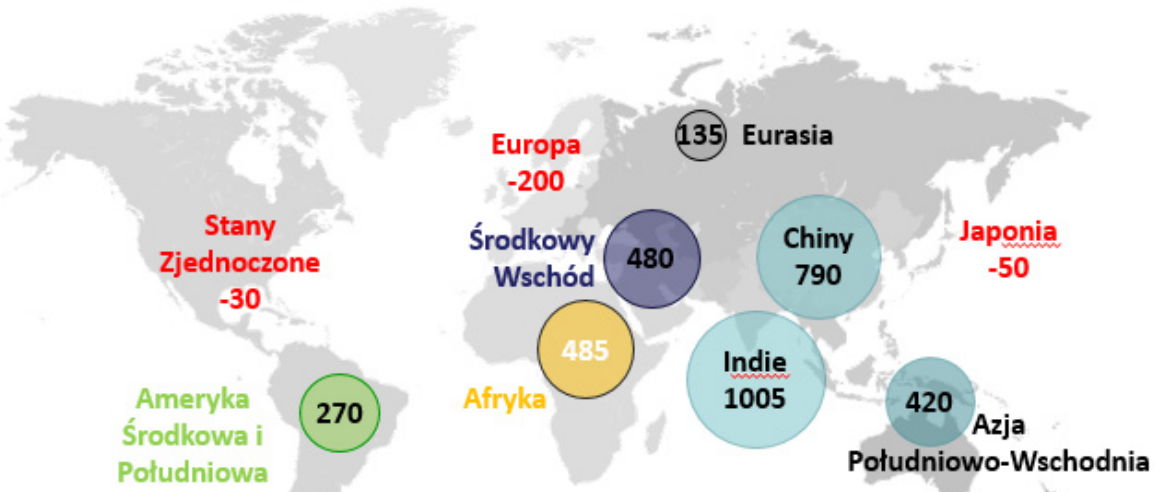

Źródło: [2].

Analizując wzrost zużycia energii na świecie należy także zwrócić uwage na wykorzystywane do tego celu nośniki energii. W roku 2016 węgiel - mimo wielu zapowiedzi dotyczących zmniejszenia jego roli - był najbardziej zyskownym commodity. Odnotowano znaczny wzrost jego cen: 50-60\% dla węgla energetycznego i 200\%(!) dla węgla koksowego.

Wzrost cen węgla tym bardziej zastanawia, że w przeciagu dwóch lat jego zużycie spadło o $2 \%$. Wzrost cen węgla nie wynikał z presji popytowej, ale był on spowodowany działaniami samych producentów. Działania te polegały m.in. na zmniejszaniu wydobycia, ograniczaniu kosztów z tym związanych oraz podejmowanie wszelkich możliwych działań mających na celu poprawę efektywności ekonomicznej. Należy wspomnieć, że w wyniku zmian w sektorze energetycznym USA dwie największe amerykańskie kompanie węglowe - Peabody i Arch - niemalże zbankrutowały w roku 2016. Chińskie kopalnie zmniejszyły np. liczbę dni roboczych z 330 do 276, co, jak szacują analitycy IEA, dało efekt w postaci wzrostu cen o 15\% [3]. 
Wraz ze wzrostem zapotrzebowania na energię były realizowane inwestycje w sektor wytwórczy elektroenergetyczny - od roku 2000 światowe moce wytwórcze oparte na węglu wzrosły o około $900 \mathrm{GW}$. Natomiast z zgodnie z prognozami do roku 2040 maja zostać oddane nowe jednostki wytwórcze o łącznej mocy tylko $400 \mathrm{GW}_{\mathrm{e}}$, przy czym należy zaznaczyć, że sporą część stanowią elektrownie znajdujące się już w budowie [2].

Analizując prognozy wzrostu zapotrzebowania na energię, należy zwrócić szczególną uwagę na Chiny, które są bardzo istotnym konsumentem nośników energii. $\mathrm{Na}$ rysunku 4 przedstawiono prognozę zmian zapotrzebowania na energię w Chinach.

\section{Rysunek 4. Prognoza zmiany zapotrzebowania na nośniki energii}
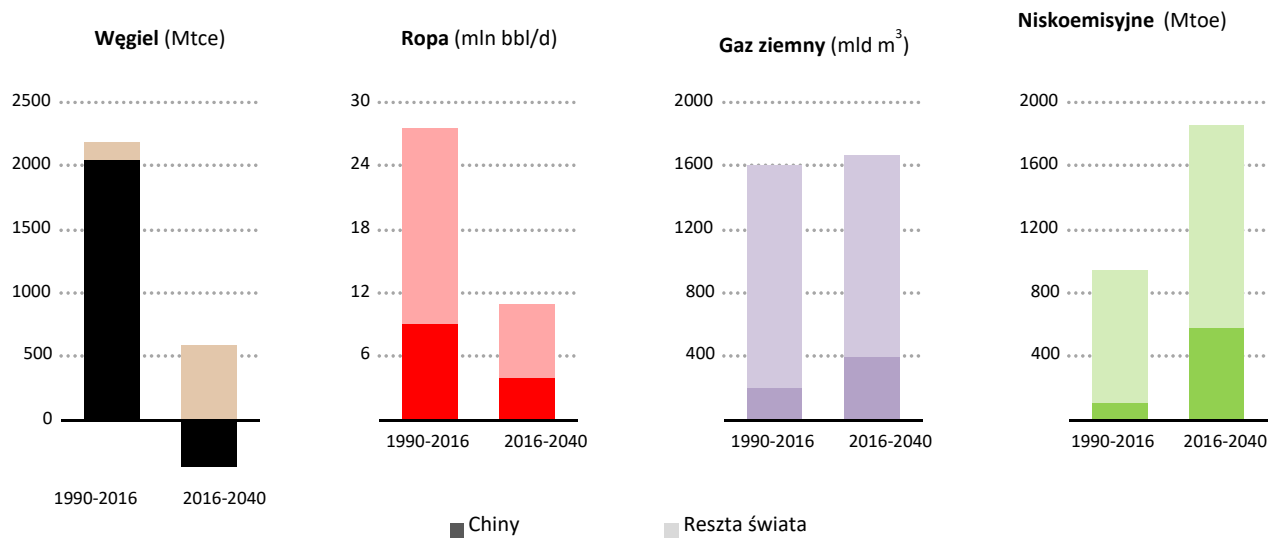

Źródło: [2].

Obecnie Chiny wkraczają w nowy etap swojego rozwoju, kładąc główny nacisk w swojej polityce energetycznej na prąd, gaz ziemny i czystsze, wysokowydajne oraz cyfrowe technologie. W minionym okresie Chiny były ukierunkowanie na przemysł ciężki, rozwój infrastruktury i eksport wyprodukowanych towarów. Dzięki temu setki milionów ludzi wyszło z ubóstwa - w tym ubóstwa energetycznego - ale zarazem pozostawiło kraj z systemem energetycznym zdominowanym przez węgiel i spuścizną poważnych problemów środowiskowych, które powodują niemal dwa miliony przedwczesnych zgonów rocznie z powodu złej jakości powietrza. Wezwanie prezydenta do rewolucji energetycznej, walki z zanieczyszczeniem i przejścia do modelu gospodarki opartej głównie na usługach, spowodowało reorientację sektora energetycznego. Wzrost popytu wyraźnie 
spadł z poziomu średnio 8\% rocznie w latach 2000-2012 do wartości mniejszej niż 2\% rocznie od roku 2012 z prognozą wzrostu na poziomie 1\% rocznie do roku 2040 [2].

\section{Działania Unii Europejskiej}

Prowadzone w ramach Unii Europejskiej działania zmierzające do minimalizacji negatywnego wpływu sektora energetycznego na środowisko doprowadziły do sytuacji, że jakiekolwiek dyskusje dotyczące udziału węgla w bilansie energetycznym któregokolwiek z państw UE spotkają się ze stanowczym sprzeciwem. $\mathrm{Na}$ podstawie osobistych doświadczeń autorów² ${ }^{2}$ można powiedzieć że samo słowo „węgiel” jest de facto słowem zakazanym w rozmowach wysokiego szczebla i przyjmuje się, że eliminując ten temat z prowadzonych rozmów jednocześnie rozwiązano problem.

Niemniej jednak, jak już na początku artykułu wskazano, pozycja węgla w bilansie energetycznym świata wydaje się być niezagrożona. Oczywiście dynamika wzrostu zapotrzebowania na węgiel, jaka miała miejsce w latach 2000-2016, nie powtórzy się w perspektywie do roku 2040. Wzrost zapotrzebowania na węgiel w dalszym ciagu będzie miał miejsce, jednak ze znacznie mniejszą dynamiką. Należy mieć na uwadze, że utrzymanie dotychczasowej dynamiki wzrostu zapotrzebowania na węgiel wywołałoby problemy, gdyż sektor wydobywczy nie byłby wstanie pokryć tak dynamicznie wzrastającego zapotrzebowania. Warto podkreślić również fakt, że zanieczyszczenia emitowane do środowiska - $\mathrm{CO}_{2}$, nie respektuja granic wyznaczonych przez człowieka. Zjawisko określane jako carbon likeage nie zniknie wraz z wyparciem ze świadomości decydentów i społeczeństwa węgla, w regionach, które go nie chcą [2].

$\mathrm{Na}$ rysunku 5 i w tabeli 1 przedstawiono prognozy zużycia węgla w zależności od realizowanej polityki regulacyjnej. W zależności od przyjętej polityki IEA prognozuje, że zapotrzebowanie na węgiel wzrośnie od 4 do 35\%. W scenariuszu utrzymania obecnych warunków regulacyjnych w całym okresie prognozy, tj. do roku 2040, popyt na węgiel wzrósłby do ponad $7 \mathrm{mld}$ ton (z 5,3 mld obecnie). Natomiast, mając na uwadze prognozy dla UE, przy założeniu wdrożenia planowanych regulacji, które są już

\footnotetext{
2 Maciej Kaliski był przedstawicielem RP w IEA w Paryżu w latach 2008-2011 i wiceministrem gospodarki odpowiedzialnym za sektor paliwowo-energetyczny w latach 2011-2012, a także Członkiem Rady Zarzadzającej i Przedstawicielem RP w Międzynarodowym Forum Energii; Miłosz Karpiński jest obecnym przedstawicielem RP przy IEA i OECD; Marian Turek jest ekspertem w zakresie techniki i technologii górniczej, ekonomiki organizacji i zarządzania górnictwa.
} 
zapowiedziane i wydają się nieuniknione prognozowane jest zmniejszenie zużycia węgla aż o $61 \%$ [ibidem].

Rysunek 5. Zużycie węgla w zależności od realizowanej polityki regulacyjnej [Mtce]

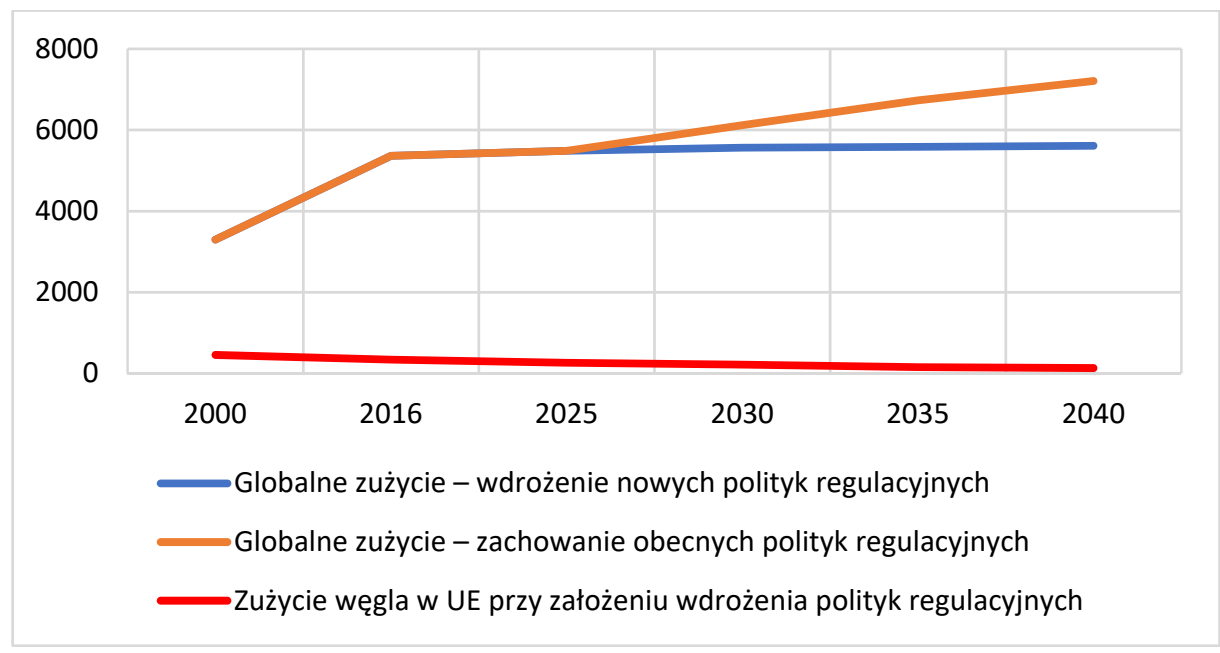

Źródło: opracowanie własne na podstawie [2].

Tabela ı. Zużycie węgla w zależności od realizowanej polityki regulacyjnej

\begin{tabular}{|c|c|c|c|c|c|c|c|c|}
\hline \multirow{3}{*}{ Wyszczególnienie } & \multirow{3}{*}{2000} & \multirow{3}{*}{2016} & \multirow{3}{*}{2025} & \multirow{2}{*}{2030} & \multirow{2}{*}{2035} & \multirow{2}{*}{2040} & \multicolumn{2}{|c|}{$2016-2040$} \\
\hline & & & & & & & Zmiana & \multirow{2}{*}{ CAARG } \\
\hline & & & & {$[$ Mtce } & & & & \\
\hline $\begin{array}{l}\text { Globalne zużycie - wdro- } \\
\text { żenie nowych polityk regu- } \\
\text { lacyjnych }\end{array}$ & 3301 & 5364 & 5488 & 5566 & 5584 & 5613 & $\begin{array}{l}+249 \\
(+4 \%)\end{array}$ & $\begin{array}{l}0,2 \% \\
\text { rocznie }\end{array}$ \\
\hline $\begin{array}{l}\text { Globalne zużycie - } \\
\text { zachowanie obecnych poli- } \\
\text { tyk regulacyjnych }\end{array}$ & 3301 & 5364 & 5488 & 6123 & 6734 & 7208 & $\begin{array}{l}+1844 \\
(+35 \%)\end{array}$ & $\begin{array}{l}1,2 \% \\
\text { rocznie }\end{array}$ \\
\hline $\begin{array}{l}\text { Zużycie węgla w UE przy } \\
\text { założeniu wdrożenia poli- } \\
\text { tyk regulacyjnych }\end{array}$ & 459 & 342 & 269 & 218 & 159 & 135 & $\begin{array}{l}+208 \\
(-61 \%)\end{array}$ & $\begin{array}{l}-3,8 \% \\
\text { rocznie }\end{array}$ \\
\hline
\end{tabular}

Źródło: [2]. 
Przedstawione przez IEA prognozy jasno wskazują, że główni konsumenci węgla nie planują rezygnacji z tego nośnika energii. Natomiast UE - na poziomie instytucjonalnym - nie przyjmuje argumentów, że zmiana systemu energetycznego - bilansu energetycznego danego państwa, regionu jest procesem długotrwałym i bardzo kosztownym, mogącym wywołać daleko idące zmiany także w sferze społecznej.

Obecnie światowe zużycie węgla wynosi 5,3 mld ton, z czego kraje Unii Europejskiej zużywają około 6\%. Przyjmując, w skali globalnej, że zostaną wdrożone nowe polityki regulacyjne, w roku 2040 UE będzie odpowiadać za 2,4\% globalnego zużycia węgla.

$\mathrm{Na}$ rysunku 6 przedstawiono zmianę udziału UE w globalnej konsumpcji węgla. Przyjmując nawet założenie, że UE całkowicie wyeliminuje węgiel ze swojego bilansu energetycznego, konsekwencje jakie to będzie miało na globalną redukcję emisji $\mathrm{CO}_{2}$, a tym samym zmiany klimatyczne będą raczej znikome. Tak wiec, stosowaną na szczeblu UE argumentację dotyczącą działań pro-klimatycznych, uzasadniająca całkowita rezygnację z węgla należy uznać za mało racjonalną [2], [5].

Rysunek 6. Udział UE w globalnym zużyciu węgla [mld ton]

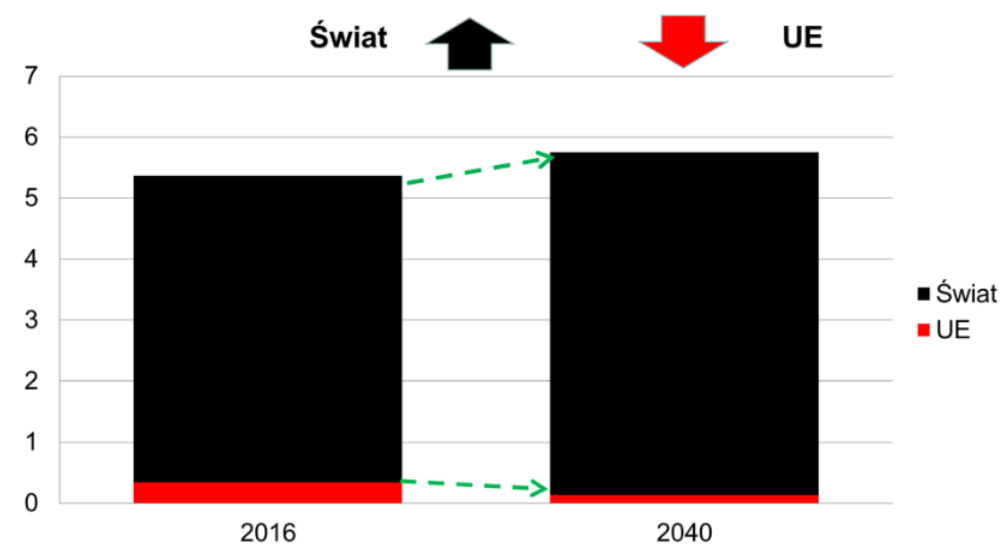

Źródło: [2].

Obecnie są intensywnie rozwijane technologie wykorzystujące odnawialne źródła energii. W roku 2016 OZE na świecie otrzymały bezpośrednie wsparcie w postaci subsydiów na poziomie 130 mld USD. Jest to kierunek słuszny, OZE powinny być istotnym elementem bilansu energetycznego, jednak trzeba mieć na uwadze, że ze względu na 
ich charakterystykę nie mogą one stanowić podstawy zaopatrzenia w energię. Dostępne obecnie, liczące się prognozy dotyczące zapotrzebowania na energię, obejmujące rozpatrywany horyzont czasowy jako główne źródło zaopatrzenia w energie przewidują kopalne nośniki energii - gdzie istotny udział stanowi węgiel [2], [4].

Zużycie węgla kamiennego w Unii Europejskiej w okresie od roku 1990 do 2016 uległo znacznej redukcji, co przedstawiono na rysunku 7 - spadek wyniósł ponad 47\%, natomiast zmniejszenie wydobycia węgla brunatnego wyniosło $42 \%$.

Rysunek 7. Zużycie węgla kamiennego w Unii Europejskiej w latach 1990-2016 w mln ton

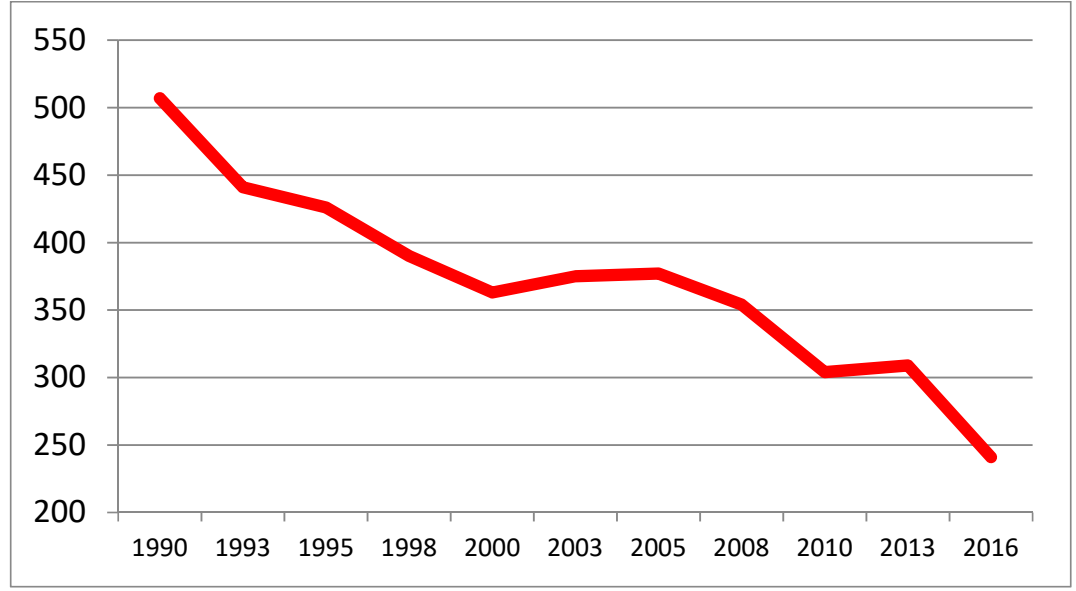

Źródło: opracowanie własne na podstawie [5].

Analizując wydobycie, należy zwrócić uwagę na drastyczny spadek zdolności wydobywczych, który osiagnął wartość 77\% [5] - co przedstawiono na rysunku 8.

Przykładowo, w roku 2016 wydobycie Niemiec zmniejszyło się aż o 39\%, czyli 4,1 mln ton - było to spowodowane zamknięciem kopalni Augusta-Wiktora w styczniu 2016 roku. Natomiast w Wielkiej Brytanii spadek ten był jeszcze większy i wyniósł 51\%, czyli 4,2 mln ton [5].

Mając na uwadze, że dynamika spadku wydobycia węgla kamiennego przewyższała spadek zużycia tego paliwa, w celu pokrycia zapotrzebowania niezbędny był import tego surowca. W roku 1990 import stanowił 26\% zapotrzebowania w Unii Europejskiej, natomiast w roku 2016 aż 64\% zapotrzebowania na węgiel kamienny było pokrywane 
importem, czyli bezpieczeństwo energetyczne w zakresie dostaw tego paliwa, spada w tym zakresie w sposób dramatyczny.

Rysunek 8. Wydobycie węgla kamiennego w Unii Europejskiej w latach 1990-2016 w mln ton

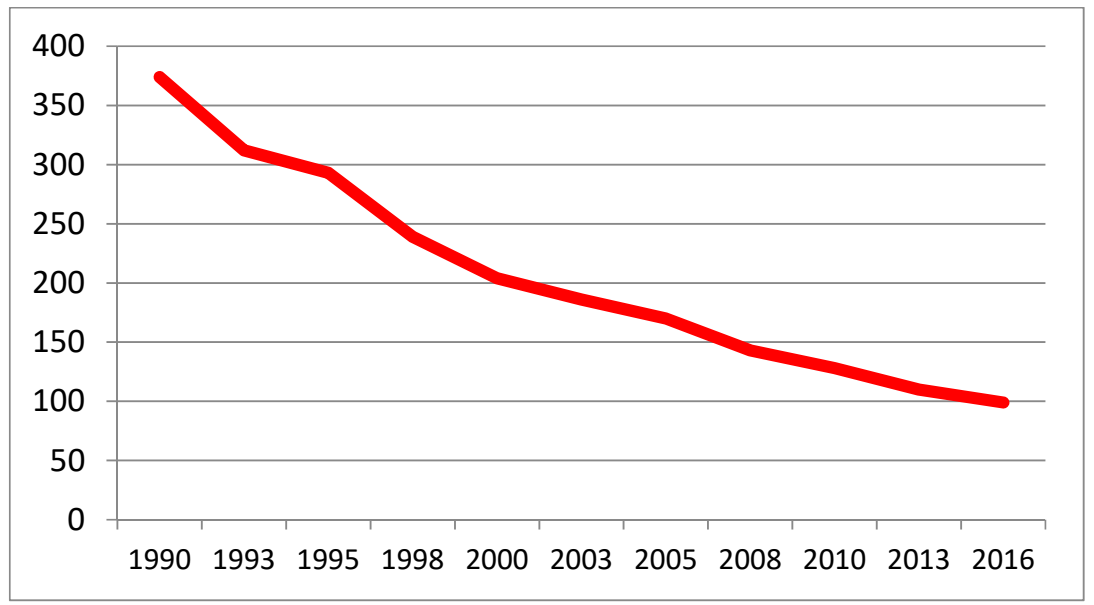

Źródło: opracowanie własne na podstawie [5].

W roku 2016 wydobycie węgla kamiennego w Unii Europejskiej wynosiło 99 mln ton, w celu pokrycia zapotrzebowania niezbędny był jego import w wysokosci $165 \mathrm{mln}$ ton. Surowiec ten importowano z następujących kierunków; Rosja - 53,4 mln ton (32,5\% importu), Kolumbia - 38,2 mln ton (23,2\%), Australia - $26 \mathrm{mln}$ ton $(15,8 \%)$, USA $-23,5 \mathrm{mln}$ ton $(14,3 \%), \mathrm{RPA}-10 \mathrm{mln}$ ton $(6,1 \%)$, Indonezja - 5,3 $\mathrm{mln}$ ton $(3,2 \%)$, inne $-8 \mathrm{mln}$ ton $(4,9 \%)$. Na uwage zasługuje fakt, że jednym z głównych orędowników na forum UE forsującym rezygnację z węgla jest Dania, podczas gdy w tym kraju import węgla w roku 2016 wzrósł o 4\% [5].

\section{Konkluzje}

W świetle przedstawionych informacji należy zadać pytania: o ile importowany węgiel jest lepszy od surowca pochodzącego z własnego wydobycia? Czy jest on tańszy, czy zapewnia miejsce pracy i rozwija gospodarkę państw unijnych? A może import węgla 
jest tylko sposobem uniknięcia odpowiedzialności za właściwe planowane wielkości wydobycia surowca, którego jako UE, mamy pod dostatkiem, rozwój nowych technologii górniczych, technologii efektywniejszego spalania, szkolenia młodzieży i edukacji na wyższym szczeblu?

Od wielu lat wydaje się, że sektor górniczy - w tym sektor polski - może funkcjonować tylko w krótkich cyklach koniunkturalnych, w istocie od 15 lat kreowanych przez Chiny. Zgodnie z prognozami IEA, Chiny - jak to zostało przedstawione - nie będa już główną siłą sprawczą na rynku węgla i wydaje się, że Unia Europejska nie mam jasnego stanowiska w sprawie wykorzystania węgla w przyszłości.

W obecnych warunkach należy zrobić wszystko, aby jak najlepiej zaadaptować się do istniejących warunków. Na wszelkich możliwych forach należy udowadniać, że węgiel nie jest paliwem straconym, a dobrze wykorzystany - przy zastosowaniu nowoczesnych technologii - może napędzać rozwój gospodarczy regionów.

Proponowana - i obecnie już będąca w końcowej fazie negocjacji - regulacja faworyzowania źródeł wytwarzania energii elektrycznej o emisyjności poniżej $550 \mathrm{~g} \mathrm{CO}_{2} / \mathrm{kWh}$ w sposób bezpośredni uderza nie tylko węgiel jako paliwo, które nie ma szans wypełnić tego warunku, ale także w Polskę jako kraj najbardziej w UE zależny w systemie elektroenergetycznym od spalania węgla.

Trzeba mieć na uwadze, że zgodnie z wszelkimi dostępnymi badaniami naukowymi przyjęcie dopuszczalnego poziomu emisji na poziomie $550 \mathrm{~g} \mathrm{CO}_{2} / \mathrm{kWh}$ jest wprost zamknięciem drogi do konsumpcji węgla w technologii, które dziś stosujemy. Przyjęcie takiego ograniczenia będzie też sprzeczne z jednym z celów, jaki postawiła sobie UE, tj. stworzenia konkurencyjnego rynku energii przy neutralności technologicznej. To o tyleż niefortunne dla całej UE, że bardzo mocno ogranicza wykorzystanie własnych zasobów energetycznych i zwiększa zależność od importu paliw w zakresie baseload capacity.

Na poziomie UE promuje się zużycie gazu ziemnego, którego zasoby na terenie Unii Europejskiej ulegają systematycznemu zmniejszeniu, a w celu pokrycia zapotrzebowania systematycznie wzrasta import. Nie jest tu istotny tylko przypadek polski, ale rzeczywiście obniżenie bezpieczeństwa energetycznego wszystkich konsumentów, zwłaszcza w czasach rosnącego, a nie malejącego napięcia na rynkach energetycznych. Unia Europejska nie jest w stanie samodzielnie zmienić biegu rzeczy w zakresie klimatu. Choć wszyscy zgadzamy się, że działania proklimatyczne są niezbędne. Unia Europejska dzisiaj zużywa 
6\% zasobów światowego węgla, a w roku 2040 ma to wynosić już tylko 2\%. Różnica zasadniczo niewielka, ale w wartościach realnych to mniej niż 3-miesięczne zużycia węgla w samych Indiach [2], [4].

Prognozuje się, że w latach 2017-2022 wzrost rynku OZE będzie w Unii Europejskiej aż o 40\% niższy niż w okresie 2011-2016, głównie z powodu niższego popytu na energię elektryczna, już widocznego nadmiaru mocy produkcyjnych z OZE i rosnących kosztów integracji sieciowej [4].

Przykładowo, średni koszt energii elektrycznej dla gospodarstwa domowego wzrósł w Niemczech latach 2007-2016 o 50\%. Subsydia do energii słonecznej i wiatrowej w roku 2016 wyniosły tam 25 mld euro, z czego 23 mld stanowiła specjalna opłata dodawana do rachunku odbiorców indywidualnych. W tym samym roku energia elektryczna pochodząca z OZE w Niemczech stanowiła 32\%, z węgla - 43\%, z instalacji jądrowych - 13\%. Emisje $\mathrm{CO}_{2}$ spadły z $1248 \mathrm{Gt}$ w roku 1990 do $880 \mathrm{Gt}$ w roku 2016 [4], [5]. Niemniej Niemcy pozostają największym emitentem $\mathrm{CO}_{2} \mathrm{w}$ Unii Europejskiej, odpowiadając za 18,3\% emisji, a węgiel jest podstawą ich systemu elektroenergetycznego.

Węgiel jest paliwem przyszłości dla całego świata, chociaż już nie będzie wszędzie najważniejszym, jednak wciąż pozostanie niezbędny. Unia Europejska może i nie chce wiedzieć o węglu na swoim terytorium, ale sama przyznaje, że bez niego sobie nie poradzi. Sektor węglowy nie jest bez wpływu na przyszłość węgla, musi jednak zmieniać powtarzalną od dekad narrację o wyższości węgla i pokazać technologicznie możliwości jego lepszego zużycia. Polska jest wyjątkiem na mapie węglowej Unii Europejskiej $i$ to stanowi dodatkowe wyzwanie monitorowania ryzyk związanych $z$ transformacja omawianego sektora.

\section{Bibliografia}

[1] BP Statistical Review of World Energy 2017 (2017), BP p.l.c., London, https:// www.bp.com/en/global/corporate/energy-economics/statistical-review-of-wo rld-energy/downloads.html

[2] World Enegy Outlook 2017 (2017), The International Energy Agency, Paris, http://www.iea.org/media/weowebsite/2017/Chap1_WEO2017.pdf 
[3] Market Report Series: Coal 2017. Analysis and Forecasts to 2022 (2017), The International Energy Agency, Paris

[4] Renewables 2017 (2017), The International Energy Agency, Paris, https://www. iea.org/publications/renewables2017/

[5] Eurostat, Energy balances, http://ec.europa.eu/eurostat/web/energy/data/ene rgy-balances 